Lobza, A. V., and Klymenko, S. Yu. "Osoblyvosti pidboru personalu na suchasnykh ukrainskykh pidpryiemstvakh, tendentsii rozvytku rekrutynhu" [Features of Staff Selection to Modern Ukrainian Enterprises, Development Trends Recruiting]. Molodyi vchenyi. Seriia «Ekonomichni nauky», no. 5 (2016): 87-90.

Mykolaichuk, I. P., and Kutsenko, A. S. "Rekrutment v systemi upravlinnia personalom pidpryiemstva" [Recruitment in the Personnel Management System of the Enterprise]. Rehionalna ekonomika ta upravlinnia, no. 5 (2016): 58-61.

Petiukh, V. M., Tkachuk, I. O., and Shkrybniuk, L. S. "Psykholohichni kompetentsii rekrutera yak faktor zabezpechennia yoho hidnoi zainiatosti“ [Psychological Competencies of Recruiter as a Factor of His Decent Employment]. Sotsialno-trudovi vidnosyny: teoriia ta praktyka. 2017. https://ir.kneu.edu.ua/bitstream/handle/2010/21600/37-48.pdf?sequence=1\&isAllowed=y

Shchetinina, L. V., Rudakova, S. H., and Hlazunova, M. V. "Metaprohramnyi portret fakhivtsia: znachennia, alhorytm rozrobky ta rezultaty vykorystannia" [Metaprograms Portrait of the Specialist: Meaning, The Algorithm of the Development and the Results of Using].
Efektyvna ekonomika. 2017. http://www.economy. nayka.com.ua/?op=1\&z=5634

Stoliaruk, Kh. S. "Profesiinyi standart fakhivtsia z upravlinnia personalom: problemy rozrobky ta vykorystannia" [Professional Standard for Personnal Manager: Problems of Development and Using]. Sotsialno-trudovi vidnosyny: teoriia ta praktyka. 2018. https://ir.kneu. edu.ua/bitstream/handle/2010/24781/Stolyaruk. pdf? sequence $=1$ \&isAllowed $=y$

Tsymbaliuk, S. O., and Pinchuk, V. O. "Otsiniuvannia konkurentospromozhnosti systemy upravlinnia personalom z vykorystanniam instrumentariiu benchmarkinhu" [Assessment of Competitiveness of the Staff Management System Using Benchmarking Tools]. Biznes Inform, no. 5 (2019): 197-203. DOI: https://doi.org/10.32983/2222-4459-2019-5-197203

Vonberh, T. V. "HR-analityka yak pidgruntia funktsionuvannia suchasnoi orhanizatsii" [HR-analytics as a Basis for the Functioning of a Modern Organization]. Ekonomichna analityka: suchasni realii ta prohnostychni mozhlyvosti. 2019. https://ir.kneu. edu.ua/bitstream/handle/2018/30855/Ek_an_19-20. pdf? sequence $=1$ \&isAllowed $=y$

\title{
HR MANAGEMENT BY VALUES AS AN INNOVATIVE WAY TO IMPROVE PERSONNEL WORK
}

\author{
${ }^{\odot 2020 ~ L I A K H ~ I . ~ 0 ., ~ L Y T V Y N ~ 0 . ~ I . ~}$
}

\author{
UDC 005.95/96+005.35]^658(477) \\ JEL: L26; M12; M14; M59
}

\section{Liakh I. O., Lytvyn O. I. HR Management by Values as an Innovative Way to Improve Personnel Work}

The article is aimed at generalizing the theoretical and practical foundations of HR management by values, allocating the difficulties of such management. The theoretical studies of Western and domestic scholars on the management by values are analyzed, which, according to the authors of the article, is one of the most effective ways to improve personnel work. Involving staff in the decision-making process is possible in any management model. Values change the behavior of the staff. Each company has its own values, and the behavior of employees is grounded on basic values. As a result of the research carried out on the basis of one of the largest banks in Ukraine - JSC CB «PrivatBank» - five main directions of improvement in motivation of labor are proposed, which are also the main problems of the financial organization, which need to be addressed. An analysis of the bank's system of motivation showed that HR management is carried out through a combination of administrative, economic and socio-psychological management methods. It is determined that the development and implementation of the values system in the company is as follows: development of key criteria for the value system (for this are created working groups of key employees); interviewing staff to determine the importance of each criterion to them; conducting a survey among employees to determine the extent to which each criterion is implemented in the company; analyzing the employees' perception of the company's existing values system based on the data obtained. Recommendations for hiring staff are proposed, as outlined in the checklist to valuate the quality of the candidate as a future employee. The difficulties of management by values at Ukrainian enterprises are substantiated. Based on the authors' own research, the core values from the employee's point of view are proposed. Also recommendations to improve the company's personnel policy in the context of $H R$ value management are proposed.

Keywords: management, staff, values, personnel work, personnel policy, motivation.

DOI: https://doi.org/10.32983/2222-4459-2020-6-328-333

Tabl.: 3. Bibl.: 10.

Liakh Inna 0. - PhD (Economics), Associate Professor of the Department of Management and Administration, Educational and Research Institute "Karazin Business School» of V. N. Karazin Kharkiv National University (1 Myronosytska Str., Kharkiv, 61002, Ukraine)

E-mail: liakh@karazin.ua

Lytvyn Olha I. - Student, Educational and Research Institute «Karazin Business School» of V. N. Karazin Kharkiv National University (1 Myronosytska Str., Kharkiv, 61002, Ukraine)

E-mail: olyalytvyn17@gmail.com

уДК 005.95/96+005.35]^658(477)

JEL: L26; M12; M14; M59

Лях І. О., Литвин О. І. Управління персоналом за чінностями як інноваційний шлях удосконалення кадрової роботи Метою статті $є$ узагальнення теоретичних і практичних засад щодо управління персоналом за цінностями, виокремлення складнощів такого управління. Проаналізовано теоретичні дослідження західних і вітчизняних учених стосовно управління за цінностями, яке, на думку авторів статmi, є одним із найбільш ефективних шляхів удосконалення кадрової роботи. Залучення персоналу в процес прийняття рішень монливе в будь-якій 
моделі менеджменту. Цінності змінюють поведінку персоналу. У кожної компанії свої цінності, та поведінка співробітників будується на базових цінностях. У результаті проведених досліджень на базі одного з найбільших банків України -АТ КБ «ПриватБанк» - запропоновано п'ять основних напрямків поліпшення мотивації праці, які також є головними проблемами фінансової організації та потребують вирішення. Аналіз системи мотивації праці в банку показав, що управління персоналом здійснюється за допомогою поєднання адміністративних, економічних і соиіально-психологічних методів управління. Визначено, що розробка та впровадження системи цінностей у компанії відбувається таким чином: розробка ключових критеріїв системи чінностей (для цього створюються робочі групи з ключових співробітників); проведення опитування серед співробітників з метою визначення важливості кожного критерію для нього; проведення опитування серед співробітників з метою визначення ступеня реалізації в компанії кожного критерію; проведення аналізу сприйняття співробітниками існуючої системи цінностей компанії на основі отриманих даних. Запропоновано рекомендації по найму персоналу, які викладені в чек-листі щодо оцінки якості кандидата як майбутнього працівника. Обгрунтовано складнощі управління за цінностями підприємствами України. Виходячи із власних досліджень запропоновано основні цінності з точки зору співробітника. Також наведено рекомендації щодо вдосконалення кадрової політики підприємства в контексті управління персоналом за цінностями.

Ключові слова: управління, персонал, цінності, кадрова робота, кадрова політика, мотивація.

Табл.: З. Бібл.: 10.

Лях Інна Олександрівна - кандидат економічних наук, доцент кафедри управління та адміністрування, Навчально-науковий інститут «Каразінська школа бізнесу» Харківського національного університету імені В. Н. Каразіна (вул. Мироносицька, 1, Харків, 61002, Україна)

E-mail: liakh@karazin.ua

Литвин Ольга Ігорівна - студентка, Навчально-науковий інститут «Каразінська школа бізнесу» Харківського національного університету імені В. Н. Каразіна (вул. Мироносицька, 1, Харків, 61002, Україна)

E-mail: olyalytvyn17@gmail.com

УДК 005.95/96+005.35]^658(477)

JEL: L26; M12; M14; M59

Лях И. А., Литвин О. И. Управление персоналом по ценностям как инновационный путь совершенствования кадровой работы

Целью статьи является обобщение теоретических и практических основ управления персонала по ценностям, выделение трудностей такого управления. Проанализированы теоретические исследования западных и отечественных ученых относительно управления по ченностям, которое, по мнению авторов статьи, является одним из наиболее эффективных путей совершенствования кадровой работы. Вовлечение персонала в процесс принятия решений возможно в любой модели менеджмента. Ценности меняют поведение персонала. У каждой компании свои ценности, и поведение сотрудников строится на базовых ценностях. В результате проведенных исследований на базе одного из крупнейших банков Украины - АО КБ «ПриватБанк» - предложено пять основных направлений улучшения мотивации труда, которые также являются главными проблемами финансовой организации, требующими решения. Анализ системы мотивации труда в банке показал, что управление персоналом осуществляется с помощью сочетания административных, экономических и социально-психологических методов управления. Определено, что разработка и внедрение системы ценностей в компании происходит следующим образом: разработка ключевых критериев системы ценностей (для этого создаются рабочие группы из ключевых сотрудников); проведение опроса среди сотрудников с целью определения важности каждого критерия для него; проведение опроса среди сотрудников с иелью определения степени реализации в компании каждого критерия; проведение анализа восприятия сотрудниками существующей системы ценностей компании на основе полученных данных. Предложены рекомендации при найме персонала, изложенные в чек-листе по оценке качества кандидата как будущего работника. Обоснованы сложности управления по ценностям предприятиями Украины. Исходя из собственных исследований предложены основные ценности с точки зрения сотрудника. Также представлены рекомендации по совершенствованию кадровой политики предприятия в контексте управления персоналом по ценностям.

Ключевые слова: управление, персонал, ценности, кадровая работа, кадровая политика, мотивация.

Табл.: 3. Библ.: 10.

Лях Инна Александровна - кандидат экономических наук, доцент кафедры управления и администрирования, Учебно-научный институт «Каразинская школа бизнеса» Харьковского национального университета имени В. Н. Каразина (ул. Мироносицкая, 1, Харьков, 61002, Украина)

E-mail: liakh@karazin.ua

Литвин Ольга Игоревна - студентка, Учебно-научный институт «Каразинская школа бизнеса» Харьковского национального университета имени В. Н. Каразина (ул. Мироносицкая, 1, Харьков, 61002, Украина)

E-mail: olyalytvyn17@gmail.com

I $\mathrm{n}$ the current context of unstable development of the Ukrainian economy, the construction of effective personnel work in enterprises in Ukraine is one of the primary conditions for them to achieve a sustainable financial result. The integration of Ukraine into the European community and other international processes, on the one hand, contribute to the introduction of new progressive management mechanisms in organizations, and, on the other hand, require new management approaches in order to increase effectiveness of personnel management systems.

According to the author, the most effective way to improve personnel work is to introduce values in the organization of personnel management.
At the turn of the century, the idea was expressed that there observed a transition from management by instructions to management by values [3]. P. Pruzan previously indicated that there was a shift from the traditional management approach, based on direct control and performance monitoring, to a value-based perspective approach [6].

Regarding the values of the personnel of organizations, the words of management classics T. Peters and R. Waterman should be cited, "...the real role of the chief executive is to manage the values of the organization" [8]. The values of the organization's personnel form corporate culture. 
The book of T. Peters and R. Waterman "In Search of Excellence: Lessons from America's Best-Run Companies" [8] is one of the first works on the problems of personnel management by values. It describes the concept of $7 \mathrm{C}$, the central component of which is corporate values as a resource for the development of an organization.

Further promotion of the idea of using corporate values to manage companies is associated with the names of S. Dolan and S. Garcia [3]. They argue that values management has a threefold goal:

+ to simplify the organizational problems that arise in connection with the growing need to adapt to changes at all levels of the company;

+ to indicate the strategic vision of the future of the company;

+ to ensure the dedication of each employee to daily high-performance work.

From a practical point of view, the goal of valuebased management is to create conditions under which employees can work independently and effectively to achieve the goals of the company [5]. K. Jaakson defines management by values as "a series of interrelated managerial activities to ensure the acceptance of relevant organizational values inside and outside the organization" [4].

$\mathrm{M}$ odern innovative approaches to social development of an enterprise stimulate and form its fundamentally new strategic directions. One of these is the effective personnel management based on the value system formed by the enterprise itself. Under modern conditions, considering the mechanism of personnel management as a whole, it is necessary to start with the value system, and then choose forms and methods of personnel management, build a personnel policy (selection, training, personnel development), take into account the influence of external and internal factors. The foundation of personnel management is organizational culture with its functions: security, integrational, regulatory, motivational, economic one, etc. [7].

In support of the trend towards the transition to value management, a number of well-known companies (General Electric, Microsoft, Levi Strauss, AT\&T, etc.) began to integrate values into their business practice. Examining a number of successful companies, J. Collins and J. Porras came to the conclusion that all of them did not change either their core goals or core values while their business strategies and practices were repeatedly adapted to changing conditions. This allowed them to become unique organizations able to innovate and achieve impressive results over a long period [2].

The work of A. Skobtseva identified the important role of corporate culture. According to the research, $86 \%$ of companies around the world recognized that the key to success of their business in highly competitive realities was a healthy corporate spirit. Due to the increased involvement of personnel, companies were able to improve the quality of work by $44 \%$ and increase profits by $22 \%$ per year [9].
American researchers K. Cameron and R. Quinn [1], analyzing the characteristics of the cultures of several hundred organizations, identified four basic types:

+ clan culture, which is similar to a family, tribe, sect, where people have a lot in common. The organization is held together by a commitment to tradition;

+ adhocracy culture (from the Latin. Ad hoc - "on occasion", situationally), which suggests a creative, innovative association. The unifying essence, value is the willingness to constant change, experimentation, innovation;

+ hierarchy culture, which implies structured and formalized environment. It is controlled by procedures;

+ market culture, which is aimed at achieving results. Competition, desire to become the best are welcome here.

In any organization, there are always elements of all basic cultures in various proportions. However, one of the described cultures always prevails.

Value-based management rests upon corporate ideology. Ideology is a system of views and ideas that determines the values of a company, its corporate culture, vision and development concept. Ideology is consciously created by chief executives as a tool for management and development of an organization [10].

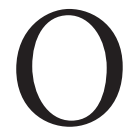
ur studies were conducted on the basis of one of the largest banks in Ukraine, Joint Stock Company Commercial Bank "PrivatBank". Personnel management at the bank is in charge of its HR Management Department, which performs the functions of personnel planning, selection and hiring; career guidance; staff adaptation; professional training and staff development.

Based on the analysis of the bank's main structural unit dealing with human resources management, we came to the conclusion that it has the following tasks: planning staffing and staff movement; organizing staff recruitment and placement; analizing professional and personal qualities of the bank's employees; organizing HR management; assessing and certifying the bank's employees; organizing staff training and development; forming a personnel reserve, organizing leadership development and career management; improving working conditions and solving social issues; developing motivation of the bank's employees.

In general, we can note that "PrivatBank", in order to retain the best employees, as well as increase its reliability and efficiency, needs to do the following:

+ to find out what its employees really want (by communicating with them and continuous feedback);

+ to provide a wide range of career opportunities and development for its employees;

+ to introduce a system of criteria and incentives that clearly show what exactly the bank expects 
from its employees, and how they should work to be rewarded.

In the optimal amount, the planned need for personnel can be facilitated by promoting the bank's employees or by hiring. Promotion may require retraining. It is also needed in order to prevent the aging of personnel.

Improving the management process is possible through staff development and enhancing the personnel assessment system.

Personnel training helps, on the one hand, increase efficiency of the bank and professional growth of its employees, on the other hand, strengthen its authority for partners and customers, and further develop the entire banking industry.

Features of the formation of the banking staff development system depends on the specifics of banking activities in general (working with clients, introducing new services, new software, new banking products, etc.), features of the bank (its strategic objectives, financial status, size, banking operations), as well as material resources, the willingness of the bank's management to invest in the development of its staff.

$\mathrm{T}$ Thus, the construction of an effective and versatile personnel development system unser the current conditions allows Joint Stock Company Commercial Bank "PrivatBank" to solve a whole range of management tasks, form a highly professional and motivated team, as well as increase the bank's competitiveness.

We can define five main areas for improving labor motivation, which are also the five main problems that need to be addressed. In view of this, the following recommendations were developed (Tbl. 1).

Table 1

Five major problems and recommendations for their solution in JSC CB "PrivatBank"

\begin{tabular}{|l|l|}
\hline \multicolumn{1}{|c|}{ Problem } & Solution Recommendations \\
\hline Material incentive & $\begin{array}{l}\text { Applying a performance- } \\
\text { based employee incentive } \\
\text { program }\end{array}$ \\
\hline Staff quality & $\begin{array}{l}\text { Introducing a continuing edu- } \\
\text { cation system }\end{array}$ \\
\hline Labour organization & $\begin{array}{l}\text { Implementing and rewarding } \\
\text { initiatives of employee, not } \\
\text { just those of managers }\end{array}$ \\
\hline $\begin{array}{l}\text { Personnel involvement in } \\
\text { the management process }\end{array}$ & $\begin{array}{l}\text { Implementing the democratic } \\
\text { principle "to hear all opinions" }\end{array}$ \\
\hline Intangible incentive & $\begin{array}{l}\text { Accounting for the emplo- } \\
\text { yee's identity in providing } \\
\text { intangible incentives }\end{array}$ \\
\hline
\end{tabular}

Source: developed by the authors.

Analysis of the system of labor motivation in "PrivatBank" showed that personnel management is carried out using a combination of administrative, economic and socio-psychological management methods. The ba- sis of the personnel incentive system is organizational and technical methods that optimize the construction of a labor efficiency management system.

The system of motivation of JSC CB "PrivatBank" and its impact on the performance of its personnel are given in Tbl. 2 .

The used socio-psychological methods are effective non-material means of improving employee performance, creating a favorable psychological climate in the team and a sense of belonging to the organization. The established at the bank stable amount of staff remuneration prevents an increase in the staff turnover and reduces the cost of finding new labor resources.

Most people go to work for a salary. Salary motivates, but not enough. Good employees are motivated by career opportunities. They think in terms of the future. Using only material incentives is not efficient even in the West. A balanced set of different motivation groupspovides a good result.

$\mathrm{I}$ n general, well-framed efforts to develop a career management system in a bank can help employees in determining their own needs for promotion, provide information on relevant career opportunities within the financial organization, and combine the needs and goals of an employee with the goals of the organization. The formation of the system can reduce the aging of human resources, which are so expensive for a bank. In addition, the career counseling system is able to provide considerable assistance to the bank's management in terms of understanding the motivation of their employees and adjusting the methods and incentive programs used.

When hiring the staff, it is advisable to follow the recommendations set out on the checklist for assessing qualities of a candidate as a future employee ( $\mathrm{Tbl} .3$ ).

We believe that the main criterion in the formation of a bank's personnel should be human values. You can prepare a person professionally very quickly, but values are difficult to change.

Difficulties in managing values:

+ the value should be similar to those of the person. Most people can not define their values, are not capable of self-identification;

+ a person cannot accept a value when at work and abandon it when leaving work. Not all employees see their work as a place they live;

+ the organization should have a leader obsessed with the idea, who could be be an example to follow;

+ when recruiting staff, a rigorous selection should be performed with consideration for the organization's values.

The introduction of changes in the company always causes resistance. It can be optimized but not eliminated. Most people don't like something in the company. A person's own goal may not coincide with the mission of the company. However, a balance between the interests 
Incentive program of JSC CB "PrivatBank" and its impact on the personnel performance

\begin{tabular}{|l|l|c|}
\hline \multicolumn{1}{|c|}{ Motivation group } & \multicolumn{1}{|c|}{ Motives and incentives } & $\begin{array}{c}\text { + To personnel performance } \\
\text { (according to expert observations } \\
\text { of the author) }\end{array}$ \\
\hline Material incentives & $\begin{array}{l}\text { Salary, participation in profits, acquisition of shares, } \\
\text { performance-based payments }\end{array}$ & $+50 \%$ \\
\hline Non-material incentives & $\begin{array}{l}\text { Diplomas of Merit, valuable gifts, title, souvenirs, } \\
\text { oral encouragement, good relations with collea- } \\
\text { gues and top managers }\end{array}$ & $+25 \%$ \\
\hline $\begin{array}{l}\text { Career Opportunity, } \\
\text { Decision-Making }\end{array}$ & $\begin{array}{l}\text { Freedom of choice and action, satisfaction } \\
\text { of an employee's own ambitions, achievement } \\
\text { of a higher position in society, application of his/ } \\
\text { her knowledge and skills, justified expectations }\end{array}$ & $+10 \%$ \\
\hline Social Security & $\begin{array}{l}\text { Health and pension insurance, social benefits, rec- } \\
\text { reational opportunities, special working conditions }\end{array}$ & $+4 \%$ \\
\hline Group motivation & $\begin{array}{l}\text { Mission, corporate culture, team affiliation, socio- } \\
\text { psychological climate }\end{array}$ & $+5 \%$ \\
\hline $\begin{array}{l}\text { Training, continuing } \\
\text { education }\end{array}$ & $\begin{array}{l}\text { Trainings, courses, seminars, adaptation of new } \\
\text { employees, new knowledge }\end{array}$ & $+5 \%$ \\
\hline
\end{tabular}

Source: developed by the authors.

Table 3

Checklist for assessing qualities of a candidate as a future employee (for the management of departments of JSC CB "PrivatBank")

\begin{tabular}{|l|l|}
\hline Qualities of the candidate & \multicolumn{1}{|c|}{ Score } \\
\hline Formal parameters & \\
\hline Personal qualities & \\
\hline Professional qualities & \\
\hline Health status & \\
\hline Appearance & \\
\hline Job specific qualities & \\
\hline
\end{tabular}

Source: developed by the authors.

of employees and the interests of the company must be achieved.

The development and implementation of a value system in a company includes the following stages

+ developing basic criteria of the value system (for this purpose, working groups of key employees are created);

+ conducting a survey among the company's employees in order to determine the importance of each criterion for him/her;

+ conducting a survey among the employees in order to determine the degree to which each criterion is implemented in the company;

+ analizing employee perceptions of the existing value system of the company based on the data obtained.

The survey is conducted among the company's employees anonymously.
Based on our own research, we offer the following core values from the point of view of an employee:

+ product (work) value:

a) interesting work;

b) decent salary;

c) career growth, promotion;

e) training and development;

g) incentive program;

+ company value:

a) company image;

b) prestige of working in the company;

c) corporate culture;

e) social programs;

g) company stability;

+ individual (leader) value:

a) leadership qualities;

b) professional qualities;

c) attention to employees;

e) encouragement of initiatives;

g) focus on achievements.

Tvolvement of personnel in the decision-making process is possible in any management model. It should

be borne in mind that values change the staff behavior. Each company has its own values and employee behavior is based on core values.

The personnel policy in JSC CB "PrivatBank" should be aimed at creating a systematic work with personnel in order to achieve not only economic effect, which is extremely important, but also social effect, which is even more important. We believe that in the personnel policy of an enterprise, two aspects of work of the HR department should be distinguished. The first direction is associated with the awareness of the person- 
nel of the rules, norms, values adopted by the enterprise. The second aspect of work of the HR department is the degree of openness of the enterprise to the outside world, i.e., orientation toward either its own or attracted personnel. Our own observations show that the focusing of a company on its own personnel, i.e., when employees understand the transparency of career building, tangible and intangible incentives, is a more productive approach in a strategic perspective.

We have defined five main recommendations for improving the personnel policy of an enterprise in the context of personnel management by values:

+ improving personnel quality due to enhancing quality of attraction and selection of specialists;

+ implementing performance-based incentives;

+ using intangible incentives depending on the values of an individual employee;

+ involving personnel in the management process on the principles of social partnership between employees of the enterprise;

+ improving the organization of labor through using feedback between managers and employees.

\section{CONCLUSIONS}

Today, in Ukraine, there are a number of factors that, on the one hand, require applying new technologies, and, on the other, introduceing personnel value-based management. Based on the foregoing, we conclude that management by values is a systematic work. It should be carried out in the following areas: implementation of team work in the company, client focus, fairness to staff, and initiative.

Thus, we can summarize the results obtained during the study. Firstly, today, prerequisites for domestic enterprises to actively introduce the concept of "value management" into the management system have formed. Secondly, it is determined that the consistency of the beliefs and values of managers with the values of employees is one of the key factors in improving team performance and company profits. This has urged the need to develop appropriate tools to identify the most significant values through the synthesis of employees's ideas at different levels.

\section{LITERATURE}

1. Cameron K. S., Quinn R. E. Diagnozing and Changing Organization Culture: Based on the Competing Values Framework. $3^{\text {rd }}$ ed. Jossey-Bass, 2011. 288 p.

2. Collins J. C., Porras J. I. Built to Last: Successful Habits of Visionary Companies. $3^{\text {rd }}$ ed. New York : Harper Business, 1994. $368 \mathrm{p}$.

3. Dolan S. L., Garcia S. Managing by values: Cultural redesign for strategic organizational change at the dawn of the twentyfrst century. Journal of Management Development. 2002. Vol. 21. Issue 2. P. 101-117. DOI: $10.1108 / 02621710210417411$
4. Jaakson K. Management by values: Are some values better than others? Journal of Management Development. 2010. Vol. 29. Issue 9. P. 795-806. DOI: 10.1108/02621711011072504

5. O'Toole J. Leading Change: The Argument for ValuesBased Leadership. New York : Ballantine Books, 1996. $304 \mathrm{p}$.

6. Pruzan P. From Control to ValuesBased Management and Accountability. Journal of Business Ethics. 1998. Vol. 17. Issue 13. P. 1379-1394. DOI: https://doi.org/10.1023/A:1006079110633

7. Діденко Н. Г. Соціальна відповідальність бізнесу як складова соціального партнерства в системі соціальнотрудових відносин в Україні. Менеджер. 2007. № 4. C. 31-35.

8. Питерс Т., Уотерман Р. В поисках эффективного управления (опыт лучших компаний) / пер. с англ. М. : Прогресс, 1986. 418 c.

9. Скобцев А. Корпоративная культура: современная философия успешного бизнеса. URL: http:// skobtsev.com/korporativnaya-kultura-sovremennayafilosofiya-uspeshnogo-biznesa/

10. Чирков О. Управление по ценностям. URL: http:// chirkovoleg.ru/materialy/stati/upravlenie-pocennostyam.html

\section{REFERENCES}

Cameron, K. S., and Quinn, R. E. Diagnozing and Changing Organization Culture: Based on the Competing Values Framework. Jossey-Bass, 2011.

Chirkov, O. "Upravleniye po tsennostyam" [Management by Values]. http://chirkovoleg.ru/materialy/stati/upravlenie-po-cennostyam.html

Collins, J. C., and Porras, J. I. Built to Last: Successful Habits of Visionary Companies. New York: Harper Business, 1994.

Didenko, N. H. "Sotsialna vidpovidalnist biznesu yak skladova sotsialnoho partnerstva $v$ systemi sotsialnotrudovykh vidnosyn v Ukraini“ [Social Responsibility of Business as a Component of Social Partnership in the System of Social and Labor Relations in Ukraine]. Menedzher, no. 4 (2007): 31-35.

Dolan, S. L., and Garcia, S. "Managing by values: Cultural redesign for strategic organizational change at the dawn of the twenty frst century". Journal of Management Development, vol. 21, no. 2 (2002): 101-117. DOI: 10.1108/02621710210417411

Jaakson, K. "Management by values: Are some values better than others?" Journal of Management Development, vol. 29 , no. 9 (2010): 795-806. DOI: 10.1108/02621711011072504

O'Toole, J. Leading Change: The Argument for Values-Based Leadership. New York: Ballantine Books, 1996.

Piters, T., and Uoterman, R. V poiskakh effektivnogo upravleniya (opyt luchshikh kompaniy) [In Search of Effective Management (Experience of the Best Companies)]. Moscow: Progress, 1986.

Pruzan, P. "From Control to Values Based Management and Accountability". Journal of Business Ethics, vol. 17, no. 13 (1998): 1379-1394.

DOI: https://doi.org/10.1023/A:1006079110633

Skobtsev, A. "Korporativnaya kultura: sovremennaya filosofiya uspeshnogo biznesa" [Corporate Culture: Modern Philosophy of Successful Business]. http:// skobtsev.com/korporativnaya-kultura-sovremennayafilosofiya-uspeshnogo-biznesa/ 